\title{
MOLECULAR AND CRYSTAL STRUCTURES OF TWO 1,2,4-BENZOTHIADIAZINE DERIVATIVES
}

\author{
P.P.S. Kumar ${ }^{1}$, P.A. Suchetan ${ }^{2}$, S. Sreenivasa ${ }^{1}$, S. Naveen ${ }^{3}$, N.K. Lokanath ${ }^{4}$, D.B.A. Kumar ${ }^{1}$ \\ ${ }^{1}$ Department of Studies and Research in Chemistry, Tumkur University, India \\ E-mail: nirmaldb@rediffmail.com (D.B.A. Kumar) \\ ${ }^{2}$ Department of Chemistry, University College of Science, Tumkur University, India \\ ${ }^{3}$ Institution of Excellence, Vijnana Bhavan, University of Mysore, Manasagangotri, India \\ ${ }^{4}$ Department of Studies in Physics, University of Mysore, Manasagangotri, India
}

\begin{abstract}
The synthesis of two 1,2,4-benzothiadiazine derivatives, namely, 6-bromo-4H-spiro[1,2,4-benzothiadiazine-3,1'-cyclobutane] 1,1-dioxide (1) and 6-bromo-1'-ethyl-4H-spiro[1,2,4-benzothiadiazine-3,4'-piperidine] 1,1-dioxide (2) is described in the present work. The synthesized compounds were studied by IR, ${ }^{1} \mathrm{H}$ and ${ }^{13} \mathrm{C} \mathrm{NMR}$, and single crystal X-ray diffraction to determine their molecular and crystal structure. In both structures the conformation of the 1,2,4thiadiazinane ring is a twisted chair and is stabilized by the intramolecular interaction of the C-H...O type. Compound $\mathbf{1}$ crystallizes in the monoclinic crystal system and space group $C 2 / c$ with the unit cell parameters $a=15.8690(17) \AA, b=12.1453(16) \AA, c=12.0152(15) \AA$, $\beta=99.686(7)^{\circ}, Z=8$ and $V=2282.7(5) \AA^{3}$. Compound 2 crystallizes in the monoclinic crystal system and space group $P 2_{1} / c$ with the unit cell parameters $a=14.5748(6) \AA, b=9.3340(5) \AA$, $c=12.4283(6) \AA, \beta=112.757(2)^{\circ}, Z=4$ and $V=1559.14(13) \AA^{3}$. In the crystal structures different packing motifs are implemented with the formation of supramolecular assemblies of different types due to classical hydrogen bonds such as $\mathrm{N}-\mathrm{H}$... O and intermolecular interactions of $\mathrm{N}-\mathrm{H} \ldots \mathrm{Br}, \mathrm{N}-\mathrm{H} \ldots \mathrm{N}, \mathrm{C}-\mathrm{H} \ldots \mathrm{O}$ types and $\pi \ldots \pi$ stacking.
\end{abstract}

DOI: $10.15372 / J S C 20150721$

K e y w o r d s: 1,2,4-benzothiadiazines, IR spectroscopy, X-ray analysis, N-H...O hydrogen bonds, $\mathrm{N}-\mathrm{H}$... Br interactions, $\mathrm{N}-\mathrm{H}$... $\mathrm{N}$ interactions, $\mathrm{C}-\mathrm{H}$...O interactions, $\pi \ldots \pi$ stacking.

\section{INTRODUCTION}

The sulfonamide class of drugs have been used since long back due to its amazing antibacterial and antifungal activities [1,2 ]. 1,2,4-Benzothiadiazine 1,1-dioxides are used as antihypertensive, diuretic, anti-diabetic, glutaminergic neuro modulators [3,4] and K-channel inhibitors [5], yet the ring system has also been known for its anti-microbial and anti-tubercular activities [6,7]. Additionally, this class of compounds has been proved to inhibit hepatitis $\mathrm{C}$ virus (HCV) replication effectively in cell based replication systems with no apparent cytotoxicity [8]. Anticancer agents containing the 1,2,4-benzothiadiazine 1,1-dioxide ring system also exhibit potent antiviral activity. Especially, benzothiadiazine-3-one 1,1-dioxide and its derivatives possess potential activity, including hypoglycemic [9], anticancer, and anti-HIV activities [10-13], and also serve as selective antagonists of CXR2 [ 14 ]. 2-Substituted-2H-1,2,4-benzothiadiazine-3(4H)one 1,1-dioxides showed varying degrees of sedative and hypotensive activities [15]. A number of benzothiadiazine 1,1-dioxide derivatives have recently been reported to display numerous biological activities [16-22]. A literature search reveals

(C) Kumar P.P.S., Suchetan P.A., Sreenivasa S., Naveen S., Lokanath N.K., Kumar D.B.A., 2015 


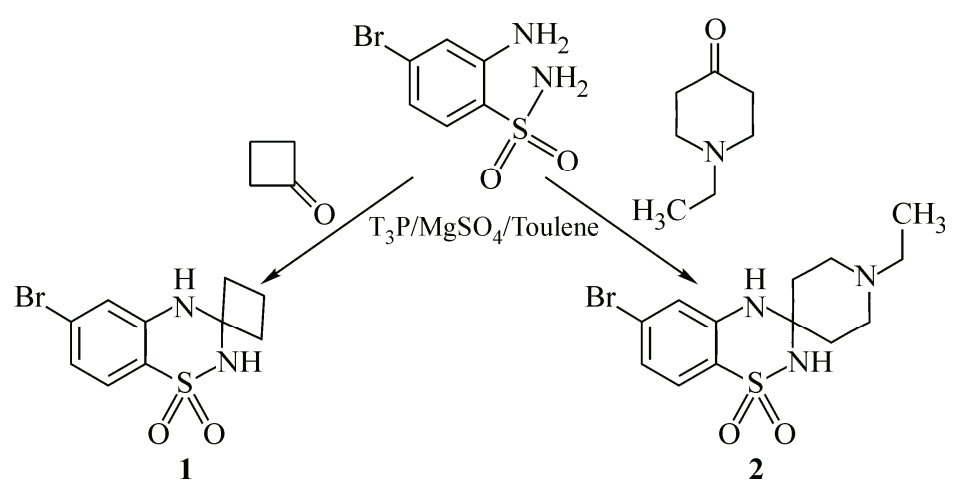

Scheme 1

that 1,2,4-benzothiadiazine 1,1-dioxides are generally synthesized either by condensation of $o$-amino benzene sulfonamides with urea at elevated temperatures [23] or by the reaction of $o$-amino benzene sulfonamide with isocyanates in DMF under reflux [24]. Although various approaches to the preparation of 1,2,4-benzothiadiazine 1,1dioxide derivatives have been reported [25-31], the development of a simpler method for the synthesis of the 1,2,4benzothiadiazine 1,1-dioxide moiety is still desirable because of their biological significance.

In search for new class of antibacterial and antifungal agents the present paper describes the synthesis of two important derivatives of 1,2,4-benzothiadiazine. 2-Amino-4-bromobenzene sulfonamide on reaction with different ketones undergoes cyclisation. The cyclisation occurs through condensation and is found to be successful when $\mathrm{T}_{3} \mathrm{P}^{\circledR}$ (poly phosphoric acid anhydride) is employed as the coupling agent under reflux, as shown in Scheme 1. Therefore, in view of the above facts compounds $\mathbf{1}$ and $\mathbf{2}$ were synthesized and characterized by IR, ${ }^{1} \mathrm{H}$ and ${ }^{13} \mathrm{C}$ NMR, and LC-MS techniques. The compounds were also subjected to single crystal X-ray diffraction studies to understand their molecular and crystal structures.

\section{EXPERIMENTAL}

Materials and methods. Melting points were determined in open capillaries and are uncorrected. Solid state FT-IR spectra were recorded as $\mathrm{KBr}$ discs on a Jasco FT-IR spectrometer. ${ }^{1} \mathrm{H}$ and ${ }^{13} \mathrm{C}$ NMR spectra were recorded in DMSO- $d_{6}$ at $399.13 \mathrm{MHz}$ and $75.50 \mathrm{MHz}$ respectively on a Bruker model Avance II instrument. All the chemical shifts were reported in parts per million (ppm) using tetramethyl silane (TMS) as the internal standard. Mass spectral data were obtained on an AGILENT LC-MS column c-18 instrument. The progresses of all the reactions were monitored by thin layer chromatography.

\section{Synthesis}

Synthesis of 6-bromo-4H-spiro[ 1,2,4-benzothiadiazine-3,1'-cyclobutane] 1,1-dioxide (1). To a cooled solution of 2-amino-4-bromo benzene sulfonamide $(5.0 \mathrm{~g}, 19.9 \mathrm{mmol})$ and anhydrous $\mathrm{MgSO}_{4}$ $(3.5 \mathrm{~g}, 29.88 \mathrm{mmol})$ in dry toluene $(60 \mathrm{ml})$, cyclobutanone $(1.5 \mathrm{~g}, 22 \mathrm{mmol})$ was added followed by slow addition of polyphosphoric acid anhydride $\left(\mathrm{T}_{3} \mathrm{P}^{\circledR}, 19 \mathrm{ml}, 29.88 \mathrm{mmol}, 50 \%\right.$ solution in ethyl acetate).The reaction mixture was then refluxed in a sealed tube at $120^{\circ} \mathrm{C}$ for $6 \mathrm{~h}$. It was cooled to $10^{\circ} \mathrm{C}$ and neutralized with a saturated $\mathrm{NaHCO}_{3}$ solution $(100 \mathrm{ml})$. The crude product was extracted with ethyl acetate $(100 \mathrm{ml})$ and was finally washed with a brine solution $(50 \mathrm{ml})$. The organic phase was dried over anhydrous sodium sulfate and concentrated to give a crude product as a brown solid. It was then dissolved in a minimum amount of ethyl acetate $(25 \mathrm{ml})$ and stirred for $1 \mathrm{~h}$ in an ice cooled bath, filtered, and washed with cold ethyl acetate $(10 \mathrm{ml} \mathrm{X} \mathrm{2)}$ ) to give pure titled compound $(4.5 \mathrm{~g}, 75 \%$ yield) as an off-white solid. M.p. $275-278{ }^{\circ} \mathrm{C}$.

Synthesis of 6-bromo-1'-ethyl-4H-spiro[1,2,4-benzothiadiazine-3,4'-piperidine] 1,1-dioxide (2). Compound 2 was prepared following the similar procedure with 1-ethyl-4-piperidone ( $2.8 \mathrm{~g}, 22 \mathrm{mmol})$ to get an off-white solid (3.8 g, $53 \%$ yield). M.p. $265-268{ }^{\circ} \mathrm{C}$.

\section{$X$-ray diffraction analysis}

Colourless prisms of both compounds were obtained from slow evaporation of the solutions of the respective compounds in ethyl acetate.

The data for the two compounds were collected on a Bruker Smart X2S diffractometer using $\mathrm{Cu} K_{\alpha}(\lambda=1.54178)$ radiation. Image processing and data reduction were performed using SAINT- 
Crystal data and structure refinement for $\mathbf{1}$ and $\mathbf{2}$

\begin{tabular}{|c|c|c|}
\hline Parameter & 1 & 2 \\
\hline CCDC number & 1023519 & 1023520 \\
\hline Empirical formula & $\mathrm{C}_{10} \mathrm{H}_{11} \mathrm{BrN}_{2} \mathrm{O}_{2} \mathrm{~S}$ & $\mathrm{C}_{13} \mathrm{H}_{18} \mathrm{BrN}_{3} \mathrm{O}_{2} \mathrm{~S}$ \\
\hline Formula weight & 303.18 & 360.27 \\
\hline Temperature, $\mathrm{K}$ & $296(2)$ & $293(2)$ \\
\hline Crystal system & Monoclinic & Monoclinic \\
\hline Space group & $C 2 / c$ & $P 2_{1} / c$ \\
\hline$a, b, c, \AA$ & $15.8690(17), 12.1453(16), 12.0152(15)$ & $14.5748(6), 9.3340(5), 12.4283(6)$ \\
\hline$\beta$, deg. & $99.686(7)$ & $112.757(2)$ \\
\hline Volume, $\AA^{3}$ & $2282.7(5)$ & $1559.14(13)$ \\
\hline$Z$ & 8 & 4 \\
\hline$\rho_{\text {calc }}, \mathrm{mg} / \mathrm{mm}^{3}$ & 1.764 & 1.535 \\
\hline Absorption coefficient & 6.529 & 4.894 \\
\hline$F(000)$ & 1216.0 & 736.0 \\
\hline Crystal size, $\mathrm{mm}$ & $0.43 \times 0.32 \times 0.18$ & $0.46 \times 0.33 \times 0.19$ \\
\hline $2 \theta$ range for data collection, deg. & 9.22 to 128.58 & 11.54 to 129 \\
\hline Index ranges & $\begin{array}{c}-18 \leq h \leq 18,-14 \leq k \leq 13 \\
-13 \leq l \leq 13\end{array}$ & $\begin{array}{c}-16 \leq h \leq 17,-10 \leq k \leq 9 \\
-14 \leq l \leq 14\end{array}$ \\
\hline Reflections collected / independent & $8176 / 1872$ & $15006 / 2569$ \\
\hline Data / restraints / parameters & $1872 / 0 / 145$ & $2569 / 0 / 182$ \\
\hline Goodness-of-fit on $F^{2}$ & 1.085 & 1.044 \\
\hline Final $R$ indexes $[I \geq 2 \sigma(I)]$ & $R_{1}=0.0430, w R_{2}=0.1170$ & $R_{1}=0.0513, w R_{2}=0.1350$ \\
\hline Final $R$ indexes [all data] & $R_{1}=0.0543, w R_{2}=0.1346$ & $R_{1}=0.0645, w R_{2}=0.1442$ \\
\hline Largest diff. peak / hole, e $/ \AA^{3}$ & $0.62 /-0.63$ & $0.57 /-0.74$ \\
\hline
\end{tabular}

Plus and XPREP [ 32 ]. The structure was solved by direct methods using SHELXS-97 [33 ]. The positions and anisotropic displacement parameters of all the atoms (excluding hydrogen) were included in the full-matrix least-square refinement using SHELXL97 [33 ] and the procedures were carried out for a few cycles until the convergence was reached. The $\mathrm{H}$ atoms were placed at the calculated positions in the riding model approximation (aromatic C-H: $0.93 \AA$; Alkyl C-H: $0.96 \AA$ ) with $U_{\text {iso }}(\mathrm{H})=$ $=1.5 U_{\text {eq }}(\mathrm{C})$ for Alkyl $\mathrm{H}$ and $U_{\text {iso }}(\mathrm{H})=1.2 U_{\text {eq }}(\mathrm{C})$ for all other $\mathrm{H}$ atoms. The $\mathrm{H}$ atom of the $\mathrm{NH}$ group was located in a difference map and later refined freely. The non-hydrogen atoms were refined anisotropically. Molecular and packing diagrams were generated using ORTEP [34] and MERCURY [35 ]. The details of crystal data and structure refinement of $\mathbf{1}$ and $\mathbf{2}$ are given in Table 1.

\section{RESULTS AND DISCUSSION}

The compounds were synthesized according to Scheme 1 and characterized by IR, ${ }^{1} \mathrm{H}$ and ${ }^{13} \mathrm{C}$ NMR, LC-MS, and single crystal X-ray diffraction techniques.

Spectral analysis. Spectral data of the synthesized compounds are in full agreement with its proposed structure.

The IR spectra of compounds 1 and 2 exhibit strong bands at $1376 \mathrm{~cm}^{-1}$ due to asymmetric $(\mathrm{S}=\mathrm{O})$ stretching and a band at $1160 \mathrm{~cm}^{-1}$ due to symmetric $(\mathrm{S}=\mathrm{O})$ stretching. A single band appearing at $3104 \mathrm{~cm}^{-1}$ due to the secondary $\mathrm{N}-\mathrm{H}$ group of sulphonamide and a band at $3305 \mathrm{~cm}^{-1}$ confirms the cyclization of sulphonamide through condensation with the ketone. The appearance of a band between $2950-2814 \mathrm{~cm}^{-1}$ due to $\mathrm{C}-\mathrm{H}$ stretching in compounds $\mathbf{1}$ and $\mathbf{2}$ confirms the presence of saturated hydrocarbons. Stretching $\mathrm{C}-\mathrm{N}$ bands have overlapped with the $\mathrm{S}=\mathrm{O}$ stretching frequencies, hence could not be identified. The ${ }^{1} \mathrm{H}$ NMR spectrum of compound 1 shows peaks at $\delta$, ppm: $7.92(\mathrm{~s}, 1 \mathrm{H}$, $\left.\mathrm{SO}_{2} \mathrm{NH}\right), 7.76(\mathrm{~s}, 1 \mathrm{H}, \mathrm{Ar}-\mathrm{H}), 7.36-7.34(\mathrm{~d}, 1 \mathrm{H}, \mathrm{Ar}-\mathrm{H}, J=8.4 \mathrm{~Hz}), 6.917-6.912(\mathrm{~d}, 1 \mathrm{H}, \mathrm{Ar}-\mathrm{H}$, $J=2.0 \mathrm{~Hz}), 3.32(\mathrm{~s}, 1 \mathrm{H}, \mathrm{NH}), 2.57-2.48\left(\mathrm{~m}, 2 \mathrm{H}, \mathrm{CH}_{2}\right), 2.18-2.10\left(\mathrm{~m}, 2 \mathrm{H}, \mathrm{CH}_{2}\right), 1.86-1.76(\mathrm{~m}$, 
Selected bond lengths $(\AA)$ and angles (deg.) for compounds $\mathbf{1}$ and $\mathbf{2}$

\begin{tabular}{|c|c|c|c|c|c|c|c|}
\hline \multicolumn{2}{|c|}{ Bond lengths } & \multicolumn{2}{|c|}{ Bond angles } & \multicolumn{2}{|c|}{ Bond lengths } & \multicolumn{2}{|c|}{ Bond angles } \\
\hline \multicolumn{4}{|c|}{ Compound 1} & \multicolumn{4}{|c|}{ Compound 2} \\
\hline $\mathrm{C} 1-\mathrm{Br} 1$ & $1.893(4)$ & $\mathrm{C} 2-\mathrm{C} 1-\mathrm{Br} 1$ & $117.8(3)$ & $\mathrm{C} 1-\mathrm{Br} 1$ & $1.904(4)$ & $\mathrm{C} 2-\mathrm{C} 1-\mathrm{Br} 1$ & $118.2(3)$ \\
\hline $\mathrm{C} 3-\mathrm{N} 1$ & $1.412(5)$ & $\mathrm{C} 6-\mathrm{C} 1-\mathrm{Br} 1$ & $119.5(3)$ & $\mathrm{C} 3-\mathrm{N} 2$ & $1.362(4)$ & $\mathrm{C} 6-\mathrm{C} 1-\mathrm{Br} 1$ & $118.9(3)$ \\
\hline $\mathrm{S} 1-\mathrm{C} 4$ & $1.745(4)$ & $\mathrm{C} 2-\mathrm{C} 3-\mathrm{N} 1$ & $118.9(4)$ & $\mathrm{S} 1-\mathrm{C} 4$ & $1.745(4)$ & $\mathrm{C} 2-\mathrm{C} 3-\mathrm{N} 2$ & $119.7(3)$ \\
\hline $\mathrm{N} 1-\mathrm{C} 7$ & $1.446(5)$ & $\mathrm{C} 4-\mathrm{C} 3-\mathrm{N} 1$ & $122.7(3)$ & $\mathrm{N} 1-\mathrm{C} 7$ & $1.478(4)$ & $\mathrm{C} 4-\mathrm{C} 3-\mathrm{N} 2$ & $122.9(3)$ \\
\hline $\mathrm{N} 2-\mathrm{C} 7$ & $1.475(5)$ & $\mathrm{C} 3-\mathrm{C} 4-\mathrm{S} 1$ & $120.8(3)$ & $\mathrm{N} 2-\mathrm{C} 7$ & $1.452(4)$ & $\mathrm{C} 3-\mathrm{C} 4-\mathrm{S} 1$ & $119.7(3)$ \\
\hline $\mathrm{S} 1-\mathrm{N} 2$ & $1.625(3)$ & $\mathrm{C} 5-\mathrm{C} 4-\mathrm{S} 1$ & $118.6(3)$ & $\mathrm{C} 9-\mathrm{N} 3$ & $1.471(4)$ & $\mathrm{C} 5-\mathrm{C} 4-\mathrm{S} 1$ & $119.2(3)$ \\
\hline $\mathrm{S} 1-\mathrm{O} 1$ & $1.434(3)$ & $\mathrm{N} 1-\mathrm{C} 7-\mathrm{C} 8$ & $119.0(3)$ & $\mathrm{C} 10-\mathrm{N} 3$ & $1.472(4)$ & $\mathrm{N} 1-\mathrm{C} 7-\mathrm{C} 8$ & $112.1(2)$ \\
\hline \multirow[t]{12}{*}{$\mathrm{S} 1-\mathrm{O} 2$} & $1.430(3)$ & $\mathrm{N} 1-\mathrm{C} 7-\mathrm{C} 10$ & $116.2(3)$ & $\mathrm{C} 12-\mathrm{N} 3$ & $1.487(4)$ & $\mathrm{N} 1-\mathrm{C} 7-\mathrm{C} 11$ & $107.9(2)$ \\
\hline & & $\mathrm{N} 1-\mathrm{C} 7-\mathrm{N} 2$ & $108.4(3)$ & $\mathrm{S} 1-\mathrm{O} 1$ & $1.426(3)$ & $\mathrm{N} 2-\mathrm{C} 7-\mathrm{C} 8$ & $110.9(3)$ \\
\hline & & $\mathrm{N} 2-\mathrm{C} 7-\mathrm{C} 8$ & $114.3(3)$ & $\mathrm{S} 1-\mathrm{O} 2$ & $1.435(2)$ & $\mathrm{N} 2-\mathrm{C} 7-\mathrm{C} 11$ & $108.3(2)$ \\
\hline & & $\mathrm{N} 2-\mathrm{C} 7-\mathrm{C} 10$ & 109.3(3) & $\mathrm{S} 1-\mathrm{N} 1$ & $1.621(2)$ & $\mathrm{N} 2-\mathrm{C} 7-\mathrm{N} 1$ & $109.4(3)$ \\
\hline & & $\mathrm{C} 3-\mathrm{N} 1-\mathrm{C} 7$ & $118.9(3)$ & & & $\mathrm{N} 3-\mathrm{C} 9-\mathrm{C} 8$ & $110.0(3)$ \\
\hline & & $\mathrm{C} 7-\mathrm{N} 2-\mathrm{S} 1$ & $116.8(3)$ & & & $\mathrm{N} 3-\mathrm{C} 10-\mathrm{C} 11$ & $110.7(3)$ \\
\hline & & $\mathrm{N} 2-\mathrm{S} 1-\mathrm{C} 4$ & $102.55(18)$ & & & $\mathrm{N} 3-\mathrm{C} 12-\mathrm{C} 13$ & $113.5(3)$ \\
\hline & & $\mathrm{O} 1-\mathrm{S} 1-\mathrm{C} 4$ & $110.18(19)$ & & & $\mathrm{O} 1-\mathrm{S} 1-\mathrm{C} 4$ & 109.61(17) \\
\hline & & $\mathrm{O} 1-\mathrm{S} 1-\mathrm{N} 2$ & $107.08(19)$ & & & $\mathrm{O} 2-\mathrm{S} 1-\mathrm{O} 1$ & $116.80(14)$ \\
\hline & & $\mathrm{O} 2-\mathrm{S} 1-\mathrm{C} 4$ & $108.8(2)$ & & & $\mathrm{O} 1-\mathrm{S} 1-\mathrm{N} 1$ & $107.42(14)$ \\
\hline & & $\mathrm{O} 2-\mathrm{S} 1-\mathrm{N} 2$ & $109.50(18)$ & & & $\mathrm{O} 2-\mathrm{S} 1-\mathrm{N} 1$ & $109.67(14)$ \\
\hline & & $\mathrm{O} 2-\mathrm{S} 1-\mathrm{O} 1$ & $117.7(2)$ & & & $\mathrm{N} 1-\mathrm{S} 1-\mathrm{C} 4$ & $103.19(14)$ \\
\hline
\end{tabular}

$\left.2 \mathrm{H}, \mathrm{CH}_{2}\right) \cdot{ }^{13} \mathrm{C}$ NMR of compound 1 shows peaks at $\delta$, ppm: $144(\mathrm{C} 1), 119(\mathrm{C} 2), 125(\mathrm{C} 3), 126(\mathrm{C} 4)$, 120 (C5), 117 (C6), 71 (C7), 39 (C8), 36 (C9), 13 (C10). The LC-MS spectrum shows the appearance of molecular ion peaks at $\mathrm{m} / \mathrm{z} 301$ and 305, confirming the structure of the compound.

The spectral analysis of compound $\mathbf{2}$ confirms its structure. The spectral data of the synthesized compounds are in full agreement with its proposed structure. The ${ }^{1} \mathrm{H}$ NMR spectrum of compound 2 shows peaks at $\delta$, ppm: $7.49-7.47(\mathrm{~d}, 1 \mathrm{H}, \mathrm{Ar}-\mathrm{H}, J=8.4 \mathrm{~Hz}), 7.28\left(\mathrm{~s}, 1 \mathrm{H}, \mathrm{SO}_{2} \mathrm{NH}\right), 6.98-6.96(\mathrm{q}$, $1 \mathrm{H}, \mathrm{Ar}-\mathrm{H}, J=3.3 \mathrm{~Hz}), 6.897-6.892(\mathrm{~d}, 1 \mathrm{H}, \mathrm{Ar}-\mathrm{H}, J=1.64 \mathrm{~Hz}), 4.58(\mathrm{~s}, 1 \mathrm{H}, \mathrm{NH}), 2.71-2.67(\mathrm{~m}$, $\left.2 \mathrm{H}, \mathrm{CH}_{2}\right), 2.59-2.49\left(\mathrm{~m}, 4 \mathrm{H}, \mathrm{CH}_{2}\right), 2.37-2.33\left(\mathrm{~d}, 2 \mathrm{H}, \mathrm{CH}_{2}, J=16 \mathrm{~Hz}\right), 1.94-1.88\left(\mathrm{q}, 2 \mathrm{H}, \mathrm{CH}_{2}\right.$, $J=2.6 \mathrm{~Hz}), 1.14-1.11\left(\mathrm{t}, 3 \mathrm{H}, \mathrm{CH}_{3}, J=6 \mathrm{~Hz}\right)$. In the LC-MS spectrum molecular ion peaks at $\mathrm{m} / \mathrm{z}$ 361 and 363 of equal intensity confirm the structure of the compound.

Crystallography. The details of the crystal data and structure refinement of the compounds are given in Table 1. The selected bond lengths and bond angles for compounds $\mathbf{1}$ and $\mathbf{2}$ are given in Table 2. Table 3 gives the details of the respective hydrogen bonding and weak interactions in $\mathbf{1}$ and $\mathbf{2}$. The

$\mathrm{T}$ a b 1 e 3

Hydrogen bond geometry in $\mathbf{1}$ and $\mathbf{2}(\AA$, deg.) (D: donor; A: acceptor; H: hydrogen)

\begin{tabular}{|c|c|c|c|c|c|c|c|c|c|}
\hline & Con & apound 1 & & & \multirow{2}{*}{\multicolumn{5}{|c|}{ Compound 2}} \\
\hline \multicolumn{5}{|c|}{ Cg represents the centroid of the benzene ring } & & & & & \\
\hline $\mathrm{D}-\mathrm{H} \ldots \mathrm{A}$ & $\mathrm{D}-\mathrm{H}$ & H...A & D...A & $\mathrm{D}-\mathrm{H} \ldots \mathrm{A}$ & $\mathrm{D}-\mathrm{H} \ldots \mathrm{A}$ & $\mathrm{D}-\mathrm{H}$ & H...A & D...A & $\mathrm{D}-\mathrm{H} \ldots \mathrm{A}$ \\
\hline $\mathrm{N} 1-\mathrm{HN} 1 \ldots \mathrm{O} 2^{\mathrm{i}}$ & 0.86 & $2.60(1)$ & $3.1113(1)$ & $120(1)$ & $\mathrm{N} 2-\mathrm{HN} 2 \ldots \mathrm{O} 2^{\mathrm{iv}}$ & 0.86 & $2.10(1)$ & $2.9484(1)$ & $170(1)$ \\
\hline $\mathrm{N} 2-\mathrm{HN} 2 \ldots \mathrm{Br} 1^{\mathrm{ii}}$ & 0.86 & $2.58(1)$ & $3.1708(1)$ & $127(1)$ & $\mathrm{N} 1-\mathrm{HN} 1 \ldots \mathrm{N} 3^{\mathrm{v}}$ & 0.86 & $2.50(1)$ & $3.0364(1)$ & 121(1) \\
\hline $\mathrm{C} 10-\mathrm{H} 10 \mathrm{~B} \ldots \mathrm{O} 2^{\mathrm{i}}$ & 0.97 & $2.54(1)$ & $3.2808(1)$ & 133(1) & $\mathrm{C} 10-\mathrm{H} 10 \mathrm{~B} \ldots \mathrm{O} 1^{\mathrm{vi}}$ & 0.97 & $2.49(1)$ & $3.2259(1)$ & $132(1)$ \\
\hline $\mathrm{C} 8-\mathrm{H} 8 \mathrm{~B} \ldots \mathrm{O} 2 *$ & 0.97 & $2.44(1)$ & $3.1374(1)$ & $129(1)$ & $\mathrm{C} 12-\mathrm{H} 12 \mathrm{~B} \ldots \mathrm{O} 1^{\mathrm{vii}}$ & 0.97 & $2.56(1)$ & $3.3775(1)$ & $142(1)$ \\
\hline $\mathrm{Cg} \ldots \mathrm{Cg}^{\mathrm{iii}}$ & - & - & $3.759(1)$ & - & $\mathrm{C} 8-\mathrm{H} 8 \mathrm{~B} \ldots \mathrm{O} 2 *$ & 0.97 & $2.38(1)$ & $3.0808(1)$ & $129(1)$ \\
\hline
\end{tabular}

Symmetry code: ${ }^{\mathrm{i}} 1 / 2-x, 1 / 2+y, 1 / 2-z ;{ }^{\text {ii }}-1 / 2+x,-1 / 2+y, z ;{ }^{\text {iii }} 1-x, y, 1 / 2-z ;{ }^{\text {iv }} x, 1 / 2-y, 1 / 2+z ;{ }^{\mathrm{v}} 1-x, 1 / 2+y$, $1 / 2-z ;{ }^{\text {vi }} 1-x,-1 / 2+y, 1 / 2-z ;$, vii $1-x, 1-y,-z$.

* Intra. 


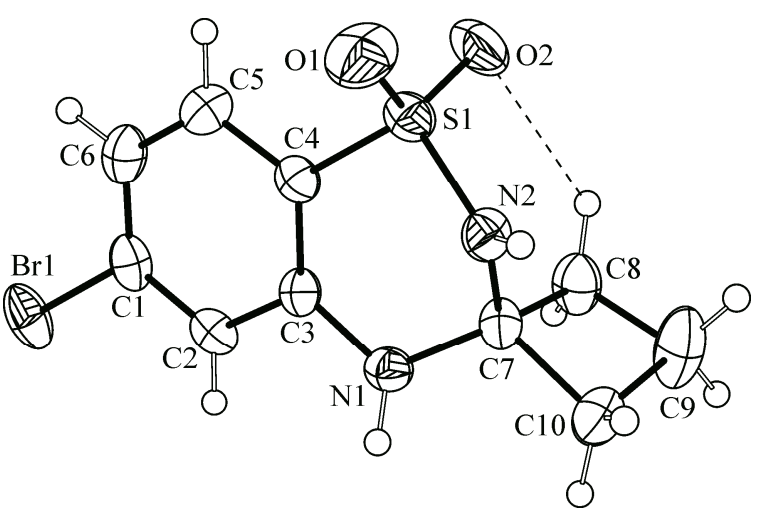

Fig. 1. Molecular structure of compound 1, showing displacement ellipsoids drawn at the $50 \%$ probability level.

Intramolecular hydrogen bonds are shown as dashed lines

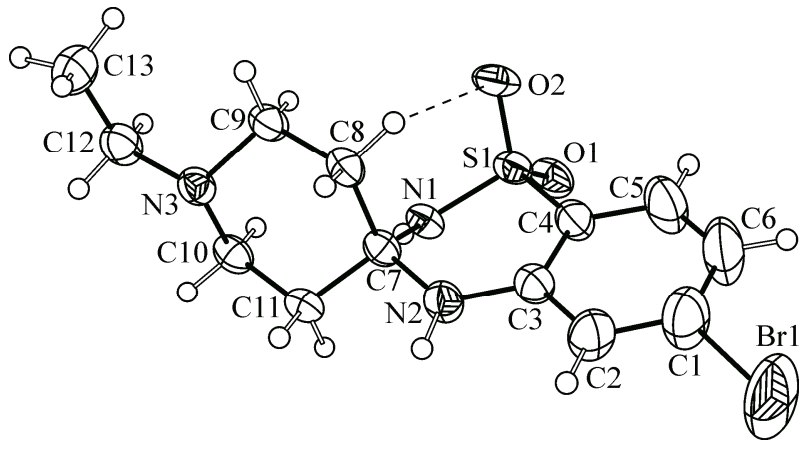

Fig. 2. Molecular structure of compound 2, showing displacement ellipsoids drawn at the $50 \%$ probability level.

Intramolecular hydrogen bonds are shown as dashed lines

ORTEP diagrams of molecules $\mathbf{1}$ and $\mathbf{2}$ with thermal ellipsoids drawn at a $50 \%$ probability are respectively shown in Figs. 1 and 2. Further, the packing diagrams of $\mathbf{1}$ are shown in Figs. 3 and 4, whereas those of $\mathbf{2}$ are shown in Figs. 5 and 6.

Molecular structure. Compound 1 crystallizes in the monoclinic crystal system and space group $C 2 / c$ with the unit cell parameters $a=15.8690(17) \AA, b=12.1453(16) \AA, c=12.0152(15) \AA, \beta=$ $=99.686(7)^{\circ}, Z=8$ and $V=2282.7(5) \AA^{3}$. The conformation of the 1,2,4-thiadiazinane ring in the structure is a twisted chair and is stabilized by the intramolecular C8-H8B ... 2 interaction (Fig. 1), forming a $\mathrm{S}(6)$ graph set motif [36]. The twisted chair conformation of the 1,2,4-thiadiazinane ring is obtained from the puckering analysis [37]; puckering amplitude $(Q)=0.4823 \AA, \theta=129.77^{\circ}, \varphi=$ $=277.4155^{\circ}$. As predicted, the cyclobutyl ring has a puckered conformation. Further, the dihedral angle between the benzene ring and the mean plane (considering non-H atoms) of the cyclobutyl ring is $73.76(1)^{\circ}$, while that between the benzene ring and the mean plane (considering non- $\mathrm{H}$ atoms) of the 1,2,4-thiadiazinane ring is $4.72(1)^{\circ}$, and that between the mean plane (considering non- $\mathrm{H}$ atoms) of the cyclobutyl ring and the mean plane (considering non-H atoms) of the 1,2,4-thiadiazinane ring is $78.44(1)^{\circ}$.

Compound 2 crystallizes in the monoclinic crystal system and space group $P 2_{1} / c$ with the unit cell parameters $a=14.5748(6) \AA, b=9.3340(5) \AA, c=12.4283(6) \AA, \beta=112.757(2)^{\circ}, Z=4$ and $V=$ $=1559.14(13) \AA^{3}$. Similar to 1 , the conformation of the 1,2,4-thiadiazinane ring in the structure is a twisted chair and is stabilized by the intramolecular C8-H8B...O2 interaction (Fig. 2), forming a

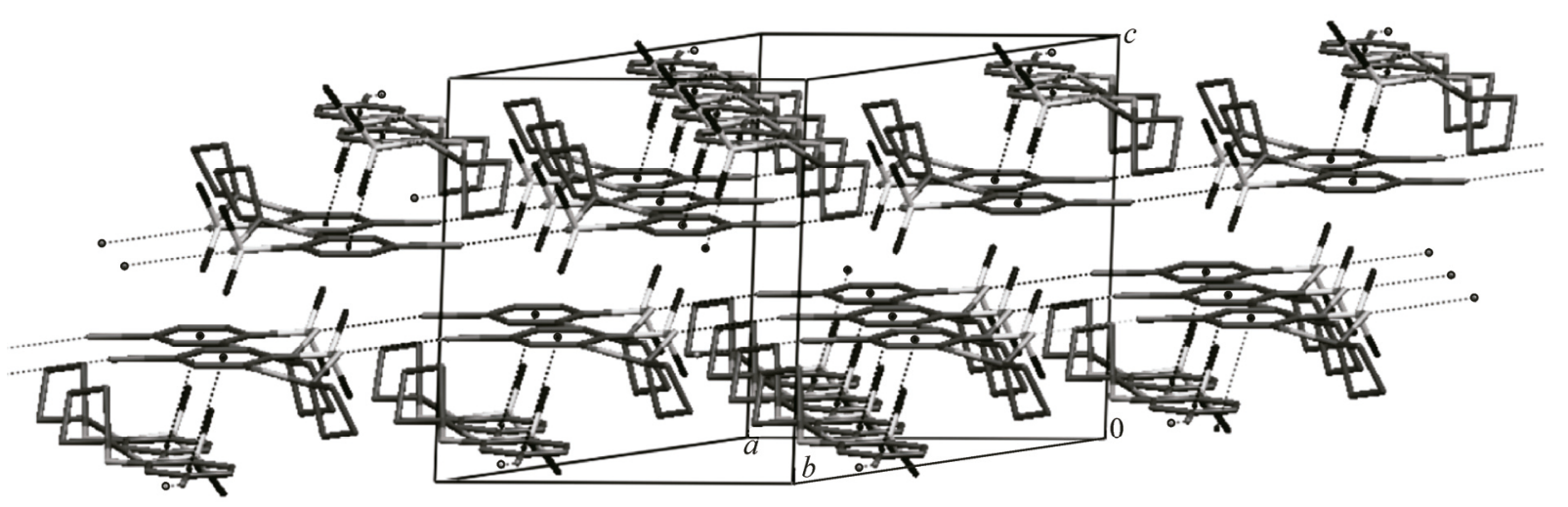

Fig. 3. Crystal Packing in $\mathbf{1}$ due to $\mathrm{N}-\mathrm{H}$... B rand $\pi \ldots \pi$ interactions. $\mathrm{H}$-atoms not involved in $\mathrm{H}$-bonding are omitted for clarity purpose 


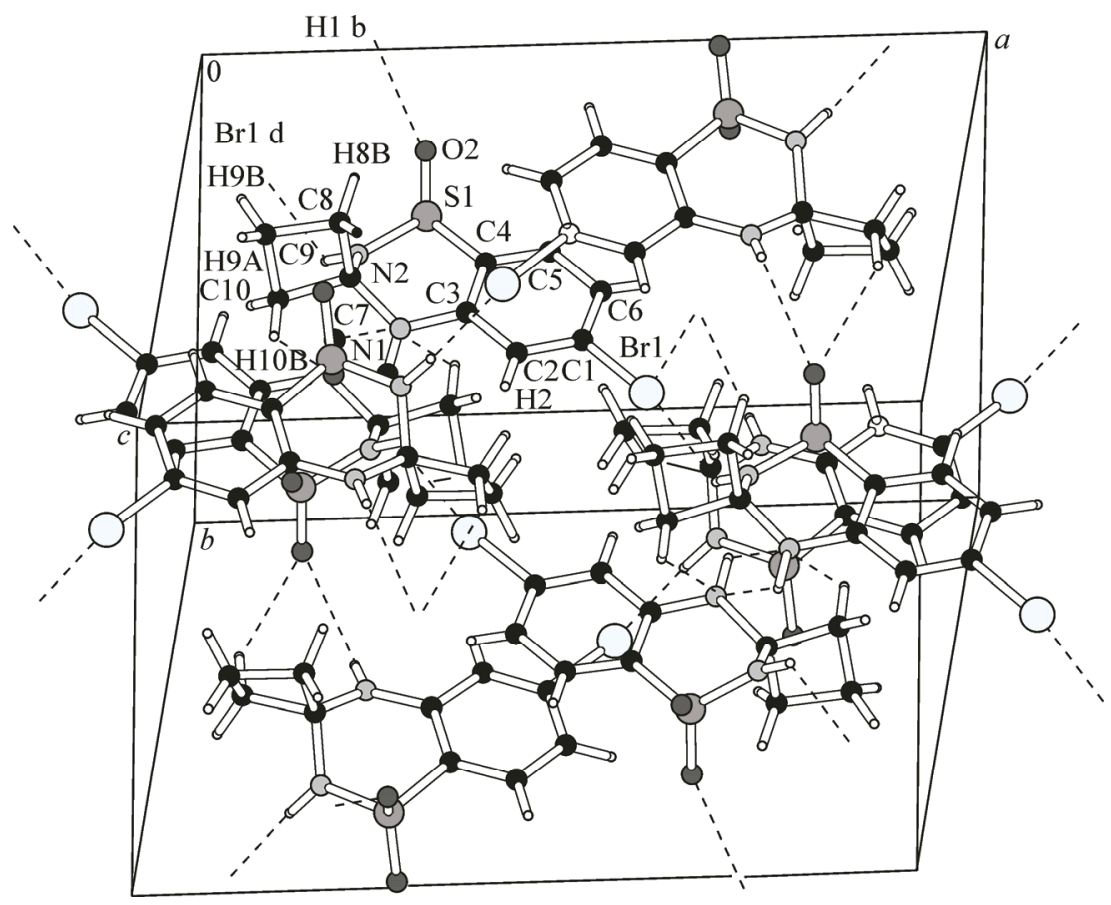

Fig. 4. $\mathrm{N}-\mathrm{H} \ldots \mathrm{O}$ and $\mathrm{C}-\mathrm{H}$... $\mathrm{O}$ interactions in $\mathbf{1}$ generating three dimensional architecture

$\mathrm{S}(6)$ graph set motif [36]. The twisted chair conformation of the 1,2,4-thiadiazinane ring is verified from the puckering analysis [37]; puckering amplitude $(Q)=0.4321 \AA, \theta=127.52^{\circ}, \varphi=260.7292^{\circ}$. Further, the piperidine ring in $\mathbf{2}$ has a chair conformation. The dihedral angle between the benzene ring and the mean plane (considering non- $\mathrm{H}$ atoms) of the piperidine ring is $73.76(1)^{\circ}$, while that between the benzene ring and the mean plane (considering non- $\mathrm{H}$ atoms) of the 1,2,4-thiadiazinane ring is $6.73(1)^{\circ}$, and that between the mean plane (considering non- $\mathrm{H}$ atoms) of the piperidine ring and the mean plane (considering non-H atoms) of the 1,2,4-thiadiazinane ring is $73.81(1)^{\circ}$.

Crystal structure. In the crystal structures of $\mathbf{1}$ and $\mathbf{2}$ different packing motifs are implemented with the formation of supramolecular assemblies of different types due to classical hydrogen bonds such as $\mathrm{N}-\mathrm{H} \ldots \mathrm{O}$, intermolecular interactions of the $\mathrm{N}-\mathrm{H} \ldots \mathrm{Br}, \mathrm{N}-\mathrm{H} \ldots \mathrm{N}, \mathrm{C}-\mathrm{H} \ldots \mathrm{O}$ types and weak $\pi \ldots \pi$ stacking interactions.

In the crystal structure of $\mathbf{1}$ there are eight molecules in the unit cell. In the absence of any strong hydrogen bonds, the first stage of packing is controlled by $\mathrm{N} 2-\mathrm{HN} 2 \ldots \mathrm{Br} 1$ interactions. Table 3 gives the details of the contact distance and the symmetry of the intermolecular interaction. Each two molecules in the unit cell are linked to one another by $\mathrm{N} 2-\mathrm{HN} 2 \ldots \mathrm{Br} 1$ interactions forming $\mathrm{C}(8)$ chains (Fig. 3). Thus, four such chains pass through each unit cell. In the second stage of packing, the two neighbouring chains are linked to one another by $\mathrm{C} 10-\mathrm{H} 10 \mathrm{~B} \ldots \mathrm{O} 2$ and $\mathrm{N} 1-\mathrm{HN} 1 \ldots \mathrm{O} 2$ interactions

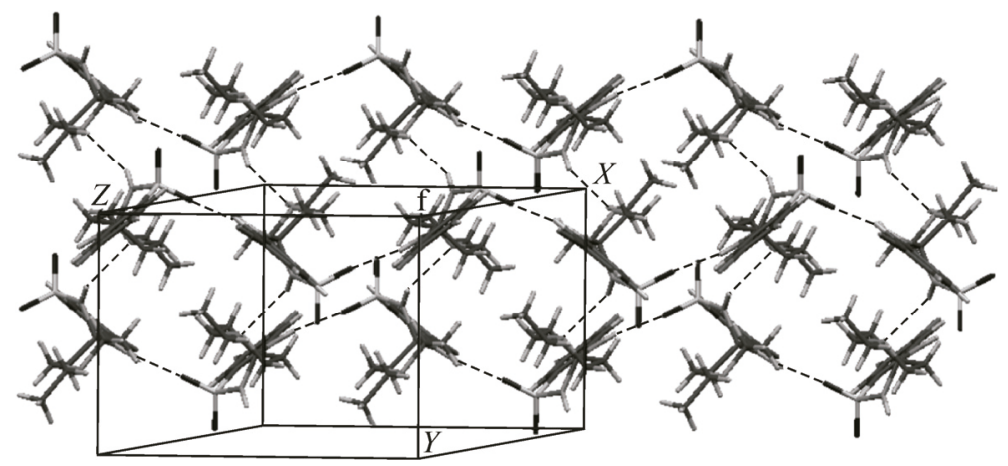

Fig. 5. Crystal packing in 2, forming $\mathrm{C}(6)$ chains via $\mathrm{N}-\mathrm{H} \ldots \mathrm{O}$ hydrogen bonds. Additional zig-zag $\mathrm{C}(6)$ chains are formed due to the $\mathrm{N}-\mathrm{H} \ldots \mathrm{N}$ interactions 


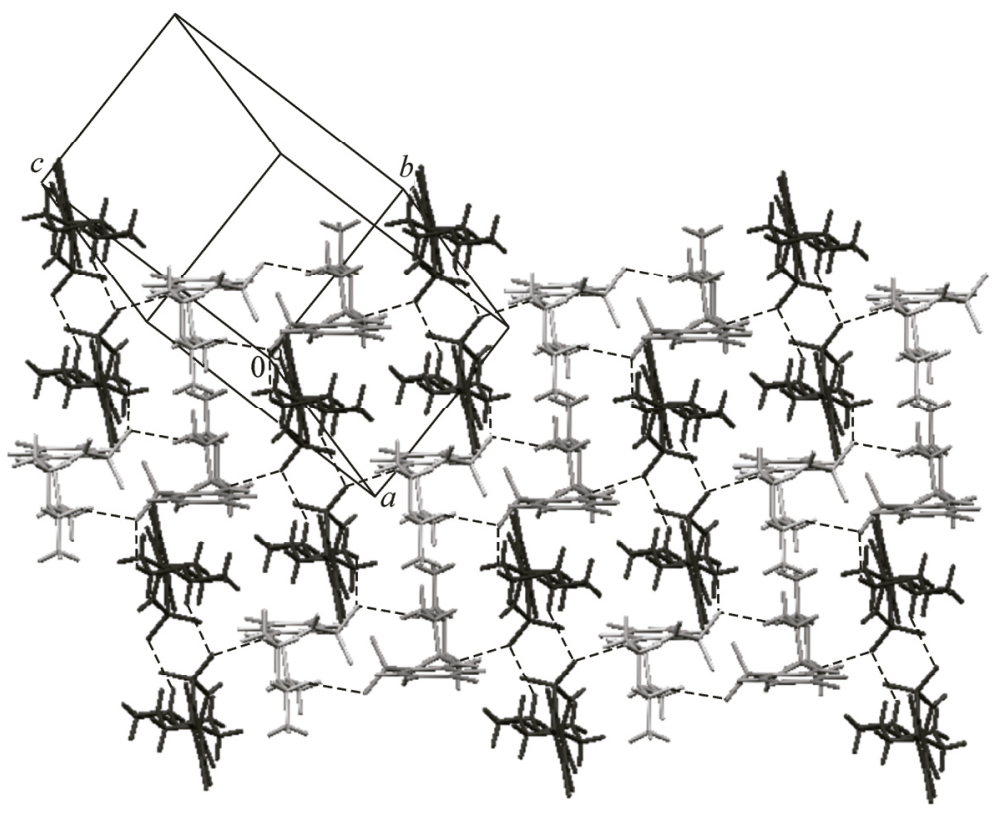

Fig. 6. Two dimensional architecture in 2 as a result of two $\mathrm{C}-\mathrm{H}$... O interactions bifurcated at the $\mathrm{O}$ atom, forming $\mathrm{C}(12)$ chains and $R_{2}^{2}(18)$ rings. For clarity purpose, the four molecules in the unit cell are shown with different colours

(Table 3), the interaction being bifurcated at the acceptor $\mathrm{O} 2$ atom. The second stage of interactions generate two $\mathrm{C}(6)$ chains (Fig. 4). The molecular packing is further strengthened by the $\pi \ldots \pi$ stacking interaction (Fig. 3) between the $\mathrm{C}(8)$ chains, forming a three dimensional supramolecular architecture.

However, in contrast to $\mathbf{1}$, the unit cell in the crystal structure of $\mathbf{2}$ contains four molecules. These four molecules are interconnected to one another, forming a tetrameric unit via $\mathrm{N} 1-\mathrm{HN} 1 \ldots \mathrm{O} 2$ hydrogen bonds and $\mathrm{N} 1-\mathrm{HN} 1 \ldots \mathrm{N} 3$ intermolecular interactions. Also, in contrast to 1, the first level of the molecular assembly in $\mathbf{2}$ is controlled by strong $\mathrm{N}-\mathrm{H}$...O hydrogen bonds (Table 3). Molecular pairs $(1,2)$ and $(3,4)$ are linked into $\mathrm{C}(6)$ chains through strong $\mathrm{N} 2-\mathrm{HN} 2 \ldots \mathrm{O} 2$ hydrogen bonds (Fig. 5), N2 being the piperidine nitrogen atom. Thus, the piperidine ring plays a significant role in controlling the supramolecular assembly. At the second level these chains are linked to one another via $\mathrm{N} 1-\mathrm{HN} 1 \ldots \mathrm{N} 3$ interactions (Table 3$)$ where the molecular pairs $(1,3)$ and $(2,4)$ are linked via zigzag $\mathrm{C}(6)$ chains (Fig. 5). It is quite striking to see that 2 does not feature interactions of the $\mathrm{N}-\mathrm{H}$...Br type, but instead structure directing $\mathrm{N}-\mathrm{H}$... N interactions are observed. The zigzag chains are further interconnected to one another via two $\mathrm{C}-\mathrm{H}$... O interactions bifurcated at the acceptor $\mathrm{O} 1$ atom (Table 3, Fig. 6), namely $\mathrm{C} 10-\mathrm{H} 10 \mathrm{~B} \ldots \mathrm{O} 1$, forming $\mathrm{C}(12)$ chains and $\mathrm{C} 12-\mathrm{H} 12 \mathrm{~B} \ldots \mathrm{O} 1$ exhibiting the R22(18) ring motif [36]. The supramolecular architecture does not feature any $\pi \ldots \pi$ stacking since the distance between the two nearest centroids is $4.979 \AA$. Therefore, the supramolecular architecture in $\mathbf{2}$ exhibits a two dimensional architecture.

\section{CONCLUSIONS}

The present work describes the synthesis of two 1,2,4-benzothiadiazine derivatives and their characterization by IR, ${ }^{1} \mathrm{H}$ and ${ }^{13} \mathrm{C}$ NMR, and LC-MS techniques. Further, single crystal X-ray diffraction studies were carried out to study the molecular and crystal structures. In the crystal structures different packing motifs are implemented with the formation of supramolecular assemblies of different types due to a difference in the intermolecular and weak interactions. The supramolecular assembly in 1 is due to interactions of the $\mathrm{N}-\mathrm{H} \ldots \mathrm{Br}, \mathrm{N}-\mathrm{H} \ldots \mathrm{O}, \mathrm{C}-\mathrm{H} \ldots \mathrm{O}$ types and a weak $\pi \ldots \pi$ interactions, while in 2 , the packing is controlled by strong $\mathrm{N}-\mathrm{H}$... O hydrogen bonds and intermolecular interactions of the $\mathrm{N}-\mathrm{H}$...N and $\mathrm{C}-\mathrm{H}$... O types. 1 exhibits a three dimensional supramolecular architecture, while in $\mathbf{2}$ it is two dimensional. 
The authors are thankful to the X-ray diffractometer facility, University of Mysore, India. P.P. Shinoj, P.A. Suchetan, S. Sreenivasa, and D.B. Aruna Kumar are thankful to Tumkur University, Tumkur for providing the laboratory and instrumental facilities to carry out the work.

CCDC 1023519 \& 1023520 contains the supplementary crystallographic data for this paper. These data can be obtained free of charge from the Cambridge Crystallographic Data Center, 12 Union Road, Cambridge CB2 1EZ, UK; fax: (+44) 1223336 033; or e-mail: deposit@ccdc.cam.ac.uk.

\section{REFERENCES}

1. Truhillo J.I., Kiefer J.R., Huang W. et al. // Bioorg. Med. Chem. Lett. -2009. - 19. - P. 908 - 911.

2. Lee C.-H., Jiang M., Cowart M. et al. // J. Med. Chem. - 2001. - 44. - P. $2133-2138$.

3. Cordi A., Spedding M., Serkiz B. et al. // Chem. Abstr. (US Patent). - 1996. - 124. - P. 261085.

4. Sarisky R.T. // J. Antimicrob. Chemother. - 2004. - 54. - P. 14.

5. Di Bella M., Monzani A., Andrisano M.G. et al.// Farmaco [Sci]. - 1983. - 38. - P. 466.

6. Kamal A., Reddy K.S., Ahmed S.K. et al. // Bioorg. Med. Chem. - 2006. - 14. - P. 650.

7. Impagnatiello F., Oberto A., Longone P. et al. // Proc. Natl. Acad. Sci. U.S.A. - 1997. - 94. - P. 7053.

8. Wales J.K., Krees S.V., Grant A.M.J. et al. // Pharmacol. Exp. Ther. - 1968. - 164. - P. 421 - 432.

9. Scozzofava A., Owa T., Mastrolorenzo A. et al. // Curr. Med. Chem. - 2003. - 10. - P. 925 - 953.

10. Casini A., Scozzafava A., Mastrolorenco A. et al. // Curr. Cancer Drug Targets. - 2002. - 2. - P. 55 - 75.

11. Scozzafava A., Casini A., Supuran C.T. // Curr. Med. Chem. - 2002. - 9. - P. 1167 - 1185.

12. Arranz E.M., Díaz J.A., Ingate S.T. et al. // Bioorg. Med. Chem. - 1999. - 7. - P. 2811 - 2822.

13. Wang Y., Busch-Petersen J., Wang F. et al. // Bioorg. Med. Chem. Lett. - 2007. - 17. - P. $3864-3867$.

14. Hayao S., Stryker W., Phillips B. et al. // J. Med. Chem. - 1968. - 11. - P. 1246 - 1248.

15. Khelili S., Kihal N., Yekhlef M. et al. // J. Med. Chem. - 2012. - 54. - P. $873-878$.

16. de Tullio P., Servais A.-C., Fillet M. et al.// J. Med. Chem. - 2011. - 54. - P. 8353 - 8361.

17. Francotte P., Goffin E., Fraikin P. et al.// J. Med. Chem. -2010. - 53. - P. $1700-1711$.

18. Pirotte B., de Tullio P., Nguyen Q.-A. et al.// J. Med. Chem. - 2010. - 53. - P. $147-154$.

19. Francotte P., de Tullio P., Goffin E. et al. // J. Med. Chem. - 2007. - 50. - P. 3153 - 3157.

20. Combrink K.D., Gulgeze H.B., Thuring J.W. et al. // Bioorg. Med. Chem. Lett. - 2007. - 17. - P. $4784-4790$.

21. Boverie S., Antoine M.-H., Somers F. et al. // J. Med. Chem. - 2005. - 48. - P. $3492-3503$.

22. Girard Y., Atkinson J.G., Rokach J. // J. Chem. Soc., Perkin Trans. - 1979. - P. 1043 - 1047.

23. Chern J.-W., Ho C.-P., Wu Y.-H. et al. // J. Heterocycl. Chem. - 1990. - 27. - P. 1909 - 1915.

24. Cherepakha A., Kovtunenko V.O., Tolmachev A., Lukin O. // Tetrahedron. - 2011. - 67. - P. 6233 - 6239.

25. Hirota S., Sakai T., Kitamura N. et al. // Tetrahedron. - 2010. - 66. - P. $653-662$.

26. Yang D., Liu H., Yang H. et al. // Adv. Synth. Catal. - 2009. - 351. - P. $1999-2004$.

27. Rolfe A., Hanson P.R. // Tetrahedron Lett. - 2009. - 50. - P. 6935 - 6937.

28. Hirota S., Kato R., Suzuki M. et al. // Eur. J. Org. Chem. - 2008. - P. 2075 - 2083.

29. Blackburn C., Achab A., Elder A. et al. // J. Org. Chem. - 2005. - 70. - P. 10206 - 10209.

30. Su W., Cai H., Yang B.J. // Chem. Res. - 2004. - P. $87-88$.

31. Makino S., Nakanishi E., Tsuji T. // J. Comb. Chem. - 2003. - 5. - P. $73-78$.

32. Bruker APEX2, SADABS and SAINT-Plus. Bruker AXS Inc., Madison, Wisconsin, USA, 2009.

33. Sheldrick G.M. // Acta Crystallogr. - 2008. - A64. - P. 112 - 122

34. Farrugia L.J. ORTEP-3 for WINDOWS-A Version of ORTEP-111 with a Graphical User Interface (GUI). // J. Appl. Crystallogr. - 1997. - 30. - P. 565 - 566.

35. Macrae C.F., Bruno I.J., Chisholm J.A. et al. // J. Appl. Crystallogr. - 2008. - 41. - P. 466 - 470.

36. Bernstein J., Davis R.E., Shimoni L., Chang N.L.// Angew. Chem. Int. Ed. Engl. - 1995. - 34. - P. 1555 1573.

37. Cremer D., Pople J.A. // J. Am. Chem. Soc. - 1975. - 97, N 6. - P. 1354 - 1358. 